Article

\title{
An Empirical Study on Green Innovation Efficiency in the Green Institutional Environment
}

\author{
Yang Gao ${ }^{1, \dagger}$, Sang-Bing Tsai ${ }^{1,2,3, *,+} \mathbb{1}$, Xingqun Xue ${ }^{1, *}$, Tingzhen Ren ${ }^{1}$, Xiaomin Du ${ }^{4}$, \\ Quan Chen ${ }^{2}$ and Jiangtao Wang ${ }^{2}$ \\ 1 School of Business, Dalian University of Technology, Panjin 124221, China; gzm@dlut.edu.cn (Y.G.); \\ 15764716872@mail.dlut.edu.cn (T.R.) \\ 2 Zhongshan Institute, University of Electronic Science and Technology, Zhongshan 528400, China; \\ zschenquan@gmail.com (Q.C.); jiangtao-w@foxmail.com (J.W.) \\ 3 Economics and Management College, Civil Aviation University of China, Tianjin 300300, China \\ 4 Department of Economic Management, Yingkou Institute of Technology, Yingkou 115014, China; \\ dxm0304058@163.com \\ * Correspondence: sangbing@hotmail.com (S.-B.T.); xxq@dlut.edu.cn (X.X) \\ $\dagger$ They are co-first authors on this work.
}

Received: 12 February 2018; Accepted: 1 March 2018; Published: 7 March 2018

\begin{abstract}
Previous studies have found that reverse technology spillover effects can promote industrial technology modernization in developing countries. However, it is still unknown whether reverse technology spillover effects can improve green innovation efficiency in developing countries. In particular, institutional uncertainties characteristic of transition economies have a significant impact on industrial modernization. Therefore, researching the impact of the institutional environment on the relationship between reverse technology spillover effects and green innovation efficiency is of great significance. In this paper, we use data from G20 countries as well as China's foreign direct investment (FDI) data to measure the effects of reverse technology spillovers and adopt the threshold effect model to explore the relationship between reverse technology spillover effects and green innovation efficiency as well as the influence of the institutional environment on this relationship, based on China's provincial panel data from 2003 to 2015. The empirical results show that the reverse technology spillover effects can effectively improve green innovation efficiency. There is a threshold for the influence of the institutional environment on the relationship between reverse technology spillover effects and green innovation efficiency. When the institutional development level surpasses the threshold value, an acceleration effect is generated. In addition, we find that the legal system is the key bottleneck in terms of improving green innovation efficiency. How to improve and perfect the path of institutional construction in China and how to enable institutions to gain threshold speed-up effects have become the major problems the Chinese government faces in institutional construction. The research results of this paper offer a reference to developing countries in regard to improving their institutions and enhancing their green innovation efficiency.
\end{abstract}

Keywords: institutional environment; sustainability; green innovation efficiency; green institutional environment; green innovation

\section{Introduction}

In recent years, outward foreign direct investment (OFDI) originating from developing countries has grown rapidly. An increasing number of developing countries have aimed to generate reverse technology spillover effects through OFDI; that is, through outward foreign investment projects, enterprises in developing countries attempt to absorb and learn advanced technology from host countries and realize a transfer of technical knowledge from their subsidiaries in host countries to 
the parent company in the home country, which leads to the overall technological development of the industry and region in the home country [1-3]. At present, the literature generally supports the existence of reverse technology spillover effects with regard to transnational corporations [4-6]. In addition, relevant studies have demonstrated the positive effect of knowledge-sharing mechanisms on green innovation efficiency [7]. However, it remains unclear whether reverse technology spillover effects can effectively improve green innovation efficiency in the investing countries or regions, especially in developing countries, including achieving regional technological progress, optimizing resource allocation and promoting the structural transformation and modernization of regional economies. The improvement of green innovation efficiency should follow the principle of economic and environmental sustainability. In particular, whenever there are technical and economical practices, a raw material or feedstock should be renewable rather than depleting [8]. Furthermore, the relationship between reverse technology spillover effects and green innovation efficiency is still inadequately studied and must be further investigated. Particularly in developing countries, the institutional uncertainties characteristic of transition economies have a critical impact on green innovation. Therefore, it is of great theoretical and practical significance to explore the impact of reverse technology spillover effects on green innovation efficiency in uncertain institutional environments.

Using China's provincial panel data from 2003 to 2015, this paper uses the threshold effect model to analyze the impact of the legal system, the economic system and the social system on the relationship between reverse technology spillover effects and green innovation efficiency. The results show that the reverse technology spillover effects can effectively improve green innovation efficiency. Furthermore, in an uncertain institutional environment, there is a threshold effect with regard to institutional factors' impact on the relationship between reverse technology spillover effects and green innovation efficiency. When China's institutional level is lower than the threshold value, there is no significant difference in the impacts of various institutional factors on the relationship between reverse technology spillover effects and green innovation efficiency. However, when the institutional level is higher than the threshold value, the impact of the legal system on the relationship is more significant than the impact of the economic system and the social system. To better impel Chinese enterprises to obtain green innovation performance through reverse technology spillover, the Chinese government needs to attach importance to the threshold effect of institutions and the path of constructing and realizing the threshold effect as well as perfecting the institutions that serve the areas of law, economy and society. Based on the empirical results, this paper analyzes the advantages and disadvantages of the institutional environment in China and provides a reference for developing countries with respect to improving green innovation efficiency.

\section{Literature Review}

\subsection{Literature Review on Reverse Technology Spillover Effects}

The role of foreign direct investment (FDI) in technology spillovers to investing countries has been theoretically and empirically confirmed at the international level [9]. Lichtenberg et al. [10] and Hsu et al. [11] found that OFDI has a significant positive impact on the productivity of investing enterprises. In addition, Liu investigates the impact of different channels for international technology spillover on the innovation performance of Chinese high-tech industries [12]. In addition to demonstrating the existence of reverse technology spillover effects, many scholars have also studied the factors influencing reverse technology spillover effects. In general, the main influencing factors include absorptive capacity [13-15], technical gaps [16-18], corporate behavior [19-21] and other factors. In addition, scholars have studied how reverse technology spillovers occur. At present, research on the mechanisms through which reverse technology spillover effects occur is basically conducted from three perspectives: the overseas research and development spillover mechanism, the operations result feedback mechanism and the internal integration mechanism [22]. Many methods have been adopted 
to study reverse technology spillovers at home and abroad; C-H-L-P [23], C-H-K-P and the method of combining panel data.

\subsection{Literature Review on Green Innovation Efficiency}

Since the industrial revolution, global problems caused by economic development, such as lack of resources and environmental degradation, have continually intensified. Domestic and foreign scholars generally believe that green innovation is an effective way to improve the environment and achieve sustainable development [24]. So-called green innovation refers to product innovation and process innovation that has the purpose of reducing adverse impacts on the environment that tend to occur in the course of economic activity [25-27]. At present, research on green innovation efficiency at home and abroad mainly focuses on influencing factors and evaluation methods. In terms of the factors affecting green innovation efficiency, the existing research generally emphasizes external environmental factors and internal factors. External factors include the government [28-30], consumers [31,32], related industries [33,34], international trade relations [35-40], etc.; internal factors include micro-level factors such as corporate goals [41,42], corporate culture [43], green resource inputs [44], entrepreneurial spirit and firm size [45-47]. In terms of the methods used to evaluate green innovation efficiency, the existing research mainly includes comprehensive evaluation and efficiency evaluation. Comprehensive evaluation of green innovation mainly uses a fuzzy evaluation method [48] and the projection pursuit evaluation model [49]; efficiency evaluation of green innovation mainly uses SFA (Stochastic Frontier Approach), DEA(Data Envelopment Analysis) [50], the entropy method [51,52] and GIS (Geographic Information System) [53].

\subsection{Literature Review on the Institutional Environment}

Previous studies of the institutional environment have mainly focused on environmental regulation. Some scholars believe that environmental regulation can promote green innovation efficiency [54,55], while other scholars believe that environmental regulation's impact on green innovation efficiency is limited [56]. In contrast to previous studies, this paper analyzes the impact of the institutional environment on green innovation efficiency based on aspects of the legal system, the economic system and the social system, operationally defining these systems as protection of intellectual property rights, government support for the region and the country's social security expenditure, respectively. Regarding the legal system, Hall et al. noted that the existence of a system for intellectual property protection is an essential condition for encouraging enterprises to innovate [57]. With regard to the economic system, the government's support for the regional economy includes many aspects. This paper mainly considers the following three aspects of government support: support for education [58], support for science and technology [59,60] and support for enterprises [61]. Like previous studies, this paper assumes that the government's support for the regional economy is positively related to the level of green innovation efficiency. As for the social security system, Jennings et al. claimed that the green urban public infrastructure provided by the government is conducive to promoting social equity and encouraging members of the community to participate in green innovation [62].

\section{Model and Data}

\subsection{Threshold Model}

The model of this paper is based on the study of Hansen [63], which gives the basic equations

$$
\mathrm{y}_{\mathrm{it}}=\mu_{\mathrm{i}}+\beta_{1}^{\prime} \mathrm{x}_{\mathrm{it}} \mathrm{I} \mathrm{q}_{\mathrm{it}} \leq \gamma+\beta_{2}^{\prime} \mathrm{x}_{\mathrm{it}} \mathrm{I} \mathrm{q}_{\mathrm{it}}>t+\mathrm{e}_{\mathrm{it}},
$$


where $\mathrm{I}(\cdot)$ is the indicator function, the subscript $\mathrm{i}$ indexes the individual, and the subscript $t$ indexes time. The dependent variable $y_{i t}$ is scalar, the threshold variable $q_{i t}$ is scalar, and the regressor $x_{i t}$ is a $k$ vector. An alternative intuitive way of writing Equation (1) is

$$
y_{i t}=\mu_{i}+\beta^{\prime} x_{i t}(\gamma)+e_{i t}
$$

where $\beta^{\prime}=\left(\beta_{1}^{\prime} \beta_{2}^{\prime}\right)^{\prime}$. The observations are divided into two "ranges" by the threshold variable $\mathrm{q}_{\mathrm{it}}$. If $\mathrm{q}_{\mathrm{it}} \leq \gamma$, the regression slope of $\mathrm{x}_{\mathrm{it}}$ is $\beta_{1}^{\prime}$; if $\mathrm{q}_{\mathrm{it}}>t$, the regression slope of $\mathrm{x}_{\mathrm{it}}$ is $\beta_{2}^{\prime}$. We also assume that the error $\mathrm{e}_{\mathrm{it}}$ is independent and identically distributed (iid) with a mean of zero and a finite variance $\sigma^{2}$.

Based on the threshold regression methods of Hansen, the threshold effect regression model of this study was set as follows:

$$
\mathrm{GIE}_{\mathrm{it}}=\alpha_{0}+\alpha_{1} \mathrm{GDP}_{\mathrm{it}}+\alpha_{2} \mathrm{HC}_{\mathrm{it}}+\alpha_{3} \mathrm{R} \& D_{\mathrm{it}}+\beta_{1} \mathrm{RTS} \times \mathrm{I}\left(\mathrm{q}_{\mathrm{it}} \leq \gamma_{1}\right)+\beta_{2} \mathrm{RTS} \times \mathrm{I}\left(\mathrm{q}_{\mathrm{it}}>\gamma_{1}\right)+\varepsilon_{\mathrm{it}}
$$

where GIE is the green innovation efficiency, GDP is the level of regional economic development of China, HC is the human capital of Chinese provinces, $R \& D$ is the Chinese provincial R\&D capital stock, and RTS is the reverse technology spillover effect that arises from the region's outward direct investment. I(·) is the indicator function representing the legal system, enterprise support, technology support, education support, social security support and environmental support. And the "." in the I(.) reprents $\mathrm{q}_{i t} \leq \gamma_{1}$ and $\mathrm{q}_{\mathrm{it}} \geq \gamma_{1}$ in the Equation (3). All data of the variables used in the model are presented as natural logarithms.

\subsection{Dependent Variable}

The dependent variable is the green innovation efficiency. Based on the work of Sun et al. [51], we use the entropy weighted TOPSIS (Technique for Order Preference by Similarity to an Ideal Solution) method to calculate the green innovation efficiency index. Patent licensing, environmental protection spending, technical market turnover and industrial governance are chosen as the evaluation indicators.

\subsection{Independent Variables}

Reverse technology spillover effect is the independent variable in this paper. According to the calculation of R\&D capital stock by L-P [10], the hypothesis of technology sourcing is tested with the foreign R\&D capital stock embodied in country i's outward FDI as follows:

$$
S_{i}^{f t}=\sum_{j \neq i} \frac{t_{i j}}{k_{j}} S_{j}^{d}
$$

where $t_{i j}$ is the FDI flow of country $i$ towards country $j$. Here, the foreign R\&D capital stock of country $i$ corresponds to the sum of all its outward FDI embodied in the R\&D capital intensity of the target countries, and $k_{j}$ is the gross fixed capital formation of country $j$. This formula is thought to yield similar results when GDP (y) is used instead of the gross fixed capital formation of country $j$. Therefore, in this paper, we use the R\&D from the host countries to measure the reverse technology spillover effect. We calculate the R\&D from the host countries as $S_{i}^{f t}=\sum_{j \neq i}{ }_{Y_{j}} S_{j}^{d}(4-2)$, where $Y_{j}$ is the GDP of country $\mathrm{j}$. However, we also need to calculate the reverse spillover effects of each province. According to previous relevant research, we can use the following formula to obtain the reverse technology spillovers of each province:

$$
S_{i t}^{f o}=\frac{\text { OFDI }_{i t}}{\sum \mathrm{OFDI}_{\mathrm{it}}} \times \sum_{\mathrm{j}=1}^{\mathrm{n}} \frac{\mathrm{OFDI}_{\mathrm{jt}}}{\mathrm{GDP}_{\mathrm{jt}}} S_{\mathrm{jt}}
$$

where OFDI $_{i t}$ is the OFDI flow from province $i$ towards country $j$ based on the data provided by the Chinese Ministry of Commerce and $S_{j t}$ is the R\&D capital stock of country $j$, which is obtained from 
the database of the World Bank. The members of the G20, with the exception of Canada, Indonesia, Saudi Arabia and the European Union (due to missing data), were selected as the host countries.

\subsection{Control Variables}

According to the existing literature, the efficiency of green innovation is affected by many factors in addition to the institutional environment. These factors include the level of regional economic development, human capital and technical endowment. This paper mainly studies the impact of the institutional environment on the relationship of reverse technology spillover effect to green innovation efficiency. Therefore, in our research, we need to control the influence of other variables. The primary control variables used in this paper are the level of regional economic development, human capital and technical endowment. The level of regional economic development is measured by the GDP of each region; the data on China's provincial GDP are taken from the China Statistical Yearbook. The human capital is measured by the number of graduates of primary schools, high schools, and universities based on data taken from the China Science and Technology Statistical Yearbook. The technical endowment is measured by green high-tech industry $R \& D$ as reported in the China Science and Technology Statistical Yearbook.

\subsection{Threshold Variables}

Many factors influence the relationship between the reverse technology spillover effect and green innovation efficiency; these include the institutional environment, human capital, the degree of financial development, the degree of opening to the outside world and so on. This paper mainly analyzes the impact of the institutional environment on the efficiency of green innovation. This paper uses the threshold effect model to analyze the threshold conditions of the institutional environment that are required to improve the efficiency of green innovation through the reverse technology spillover effect so that all regions in China can correctly understand the advantages and disadvantages of their own institutional systems. In addition, we put forward some policy recommendations for specific regions of China and other emerging economies that may improve the efficiency of green innovation.

A country's institutional environment comprises relatively stable rules, social norms, and cognitive structures [64]. Oxley measured the institutional environment by evaluating intellectual property protection and analyzed the impact of the institutional environment on the structure of inter-firm alliances [65]. Spencer et al. measured the impact of the national institutional environment on the activities of specific enterprises by assessing the financial support of the state for the enterprise [66]. Li et al. divided the system into a legal system and an economic system [67]. The legal system was mainly measured by the protection of intellectual property rights, while the economic system mainly included three aspects: government support, financial support and policy openness. The government support mainly included enterprise support, educational support and technological support. Based on previous studies, we added a social system index to measure the impact of the government's informal institutions on the relationship between the reverse technology spillover effect and green innovation capability. The social system mainly includes environmental support and social security support. In our work, the threshold variables of the institutional environment include three aspects: the legal system, economic institutions and social institutions. The legal system is introduced and enforced by the state, and the effectiveness of the legal system is measured mainly through the number of IP (Intellectual Property) cases closed. To analyze the impact of the economic system on the efficiency of green innovation, government support is measured by three indicators: the total amount of fixed assets in state-owned enterprises, expenditures on education in local finance, and expenditures on science and technology in local finance. Finally, we also analyze the impact of the social system on the relationship of the reverse technology spillover effect to green innovation efficiency by assessing the two sub-indicators, social security support and environmental support. Environmental support and social security support are measured by environmental expenditures and local financial social 
security and employment expenditures, respectively. And the specific index and data sources of main variables can be seen in Table 1.

Table 1. Index and data sources of main variables.

\begin{tabular}{|c|c|c|}
\hline Name & Index & Data Sources \\
\hline \multirow{4}{*}{ green innovation efficiency (GIE) } & patent licensing & $\begin{array}{l}\text { China Science and Technology } \\
\text { Statistical Yearbook }\end{array}$ \\
\hline & environmental protection spending & China Statistical Yearbook \\
\hline & technical market turnover & $\begin{array}{l}\text { China Science and Technology } \\
\text { Statistical Yearbook }\end{array}$ \\
\hline & $\begin{array}{l}\text { the investments completed by } \\
\text { industrial governance }\end{array}$ & China Statistical Yearbook \\
\hline \multirow{3}{*}{$\begin{array}{l}\text { reverse technology } \\
\text { spillovers (RTS) }\end{array}$} & national GDP & World Bank \\
\hline & national R\&D capital stock & World Bank \\
\hline & provincial outward foreign investment stock & Chinese Ministry of Commerce \\
\hline GDP (GDP) & gross domestic product & China Statistical Yearbook \\
\hline human capital (HC) & $\begin{array}{l}\text { number of primary school, high school, } \\
\text { and university graduates }\end{array}$ & $\begin{array}{l}\text { China Science and Technology } \\
\text { Statistical Yearbook }\end{array}$ \\
\hline green $\mathrm{R} \& D(\mathrm{R} \& \mathrm{D})$ & green high-tech industry R\&D & $\begin{array}{l}\text { China Science and Technology } \\
\text { Statistical Yearbook }\end{array}$ \\
\hline legal system (LS) & $\begin{array}{l}\text { number of infringements of intellectual } \\
\text { property rights }\end{array}$ & State Intellectual Property Office \\
\hline enterprise support (ETS) & total fixed assets of state-owned enterprises & National Bureau of Statistics \\
\hline technology support (TS) & $\begin{array}{l}\text { local financial science and } \\
\text { technology expenditure }\end{array}$ & National Bureau of Statistics \\
\hline education support (ECS) & local financial education expenditure & National Bureau of Statistics \\
\hline social security support (SSS) & $\begin{array}{l}\text { local financial social security and } \\
\text { employment expenditure }\end{array}$ & National Bureau of Statistics \\
\hline environmental support (EVS) & $\begin{array}{l}\text { local financial and environmental } \\
\text { protection expenditure }\end{array}$ & National Bureau of Statistics \\
\hline
\end{tabular}

Note: Abbreviations of the variables are shown in parentheses.

Table 2 reports the descriptive statistics of the main variables assessed in this work. The values of the variables reported in this paper obviously differ among regions; this reflects the imbalance in the systems of the institutional environment in different regions. In terms of the efficiency of green innovation, the differences among the regions are obvious. The maximum efficiency is 1.641, and the minimum efficiency is 0.757 . In terms of environmental factors, the differences among the regions in terms of enterprise support are the largest, whereas the differences in technical support and environmental support are relatively small.

Table 2. Descriptive statistics.

\begin{tabular}{|c|c|c|c|c|c|}
\hline & Mean & Median & Maximum & Minimum & Std. Dev. \\
\hline GIE & 1.218 & 1.230 & 1.641 & 0.757 & 0.173 \\
\hline RTS & 2.632 & 0.658 & 42.914 & 0.001 & 5.229 \\
\hline GDP & 1.412 & 1.045 & 7.217 & 0.046 & 1.301 \\
\hline $\mathrm{HC}$ & 912.318 & 804.450 & 2497.060 & 77.700 & 573.580 \\
\hline R\&D & 322.127 & 75.037 & 7191.814 & 0.036 & 773.168 \\
\hline LS & 104.915 & 25.000 & 7976.000 & 0.000 & 486.606 \\
\hline ETS & 363.404 & 339.972 & 1142.340 & 19.906 & 222.705 \\
\hline TS & 53.786 & 28.593 & 564.500 & 0.834 & 70.045 \\
\hline ECS & 449.348 & 363.039 & 2004.074 & 18.852 & 358.881 \\
\hline SSS & 296.212 & 239.573 & 1113.941 & 9.781 & 215.954 \\
\hline EVS & 67.171 & 53.618 & 316.639 & 0.754 & 56.925 \\
\hline
\end{tabular}




\section{Empirical Analysis}

The empirical analysis is conducted by evaluating equation using six threshold variables (legal system, enterprise support, technology, education, social security and environment). The results of the empirical analysis are shown in Table 3. As a control variable, GDP has no effect on green innovation efficiency except the first regression results. Human capital and green high-tech industry R\&D has a positive effect on green innovation efficiency in all of the regression results.

When the above six threshold variables (legal system, enterprise support, technology, education, social security and environment) were selected as the institutional environment, the F test results showed that all six of the variables have threshold effects on the influence of reverse technology spillover effects on green innovation efficiency. The threshold values are 6.213, 8.474, 5.337, 5.745, 6.132 and 7.920 for the legal system, enterprise support, technology, education, social security and the environment, respectively. With respect to the legal system, the coefficient of reverse technology spillover effect on green innovation efficiency is 0.037 when the legal system is under the threshold value, and the coefficient increases to 0.148 when the legal system is over the threshold value. Enterprise support, technology, education, social security and environment yield similar results; the coefficients are not significant when these variables are below their threshold values. In addition, the coefficients are $0.077,0.102,0.066,0.076$ and 0.063 , respectively, when these variables exceed their threshold values.

Table 3. Estimated results of threshold model.

\begin{tabular}{ccccccc}
\hline \multirow{2}{*}{ Legal System } & \multicolumn{2}{c}{ Economic Institution } & \multicolumn{2}{c}{ Social Institution } \\
\cline { 2 - 7 } & LS & ETS & TS & ECS & SSS & EVS \\
\hline \multirow{2}{*}{ GDP } & $-0.151^{* *}$ & 0.089 & -0.102 & -0.082 & -0.101 & -0.085 \\
& -0.039 & -0.058 & -0.058 & -0.059 & -0.058 & -0.056 \\
\hline \multirow{2}{*}{ HC } & $0.116^{* *}$ & $0.260^{* *}$ & $0.223^{* *}$ & $0.242 * *$ & $0.237^{* *}$ & $0.245^{* *}$ \\
& -0.032 & -0.07 & -0.065 & -0.061 & -0.66 & -0.062 \\
\hline \multirow{2}{*}{ R\&D } & $0.027^{*}$ & $0.054^{*}$ & $0.058^{* *}$ & $0.059^{* *}$ & $0.057^{* *}$ & $0.058^{* *}$ \\
\hline \multirow{2}{*}{ RTS*I $(\mathrm{q} \leq \gamma)$} & -0.011 & -0.021 & -0.02 & -0.019 & -0.021 & -0.016 \\
\hline \multirow{2}{*}{ RTS*I $(\mathrm{q}>\mathrm{T})$} & $0.037^{* *}$ & 0.014 & 0.024 & 0.005 & 0.018 & 0.009 \\
\hline $\mathrm{R}^{2}$ & -0.014 & -0.016 & -0.016 & -0.016 & -0.017 & -0.016 \\
\hline Threshold value & $0.148^{* *}$ & $0.077^{* *}$ & $0.102 * *$ & $0.066^{* *}$ & $0.076^{* *}$ & $0.063 * *$ \\
\hline F-statistic & -0.045 & -0.023 & -0.032 & -0.018 & -0.026 & -0.018 \\
\hline Hausman test & 0.183 & 0.181 & 0.187 & 0.176 & 0.192 & 0.174 \\
\hline
\end{tabular}

Notes: ${ }^{* *}$ and ${ }^{*}$ denote statistical significance at the $1 \%$ and $5 \%$ levels, respectively. Robust standard errors are reported in parentheses. The F-statistic indicates the significance of the threshold value. According to the Hausman test results, all the regressions take the fixed effects.

\section{Discussion}

\subsection{Theoretical Significance}

The innovation of this paper is mainly reflected in the following two aspects. First, most existing research on green innovation efficiency focuses on analyzing the impact of factors such as environmental regulation and FDI spillover mechanisms on green innovation efficiency and ignores the impact of reverse technology spillover effects on green innovation efficiency. This paper studies the impact of reverse technology spillover effects on green innovation efficiency in developing countries during their institutional transition period, supplementing existing research on the mechanisms 
influencing green innovation efficiency and providing a new direction for future research on reverse technology spillover effects and green innovation efficiency. Second, unlike previous studies, this paper explores the influence of institutional factors on the relationship between reverse technology spillover effects and green innovation efficiency in uncertain institutional environments based on various regional institutional systems and defines the specific institutional thresholds required for reverse technology spillover effects to generate impacts on green innovation efficiency. The level of institutional threshold can reflect the level of China's institutional construction and the critical point at which the institution takes effect, a point that is of some relevance to China's institutional construction. In its research process, this paper explores how China's institutional construction promotes the realization of green innovation efficiency under the effects of reverse spillover from the three perspectives of the legal system, the economic system and the social system. The data, especially those used in the analysis of institutional thresholds, are obtained from different regions, reflecting the varied characteristics of regional economic development. Due to the different levels of economic development in different regions of China, the institutional threshold values vary. Studies of this type have significant value as a reference for refining institutional construction in the context of regional characteristics in China and emphasizing the construction and development of institutions based on regional balance.

\subsection{Practical Significance}

First, the research results show that improvements in green innovation efficiency can be achieved through reverse technology spillover from OFDI. This conclusion encourages developing countries to support the OFDI activities of domestic enterprises and to provide policy support and tax subsidies for these activities. Enterprises should also value technology acquisition and absorption in the context of FDI and should enhance their capacity to absorb reverse technology spillover effects. Second, for most developing countries, including China, institutional uncertainties characteristic of transition economies have a substantial impact on the economic development and technological innovation of these countries. The government first needs to improve the institutional environment, including the legal system, the economic system and the social system. In the process of improving these systems, the government should first explore the developmental path of institutional construction based on the threshold effect to enable the institutional construction to achieve the threshold effect and thereby increase the role of institutional construction in the outward investment of enterprises. At the same time, the government must place particular emphasis on regional characteristics in the context of regional imbalances and design system frameworks according to local conditions, including prioritizing support for backward areas and the development of bottleneck systems. Finally, the evaluation of regional green innovation efficiency is an important means of testing regional growth processes and results, correcting deviations and forecasting future economic development modes. Comparisons among regions will help the government clarify difficult problems of green economy development in different regions. The government can refer to the successful experience of highly efficient regions, integrate regional economic and environmental resources, use local institutional advantages, and as a result enhance its efficiency in terms of green growth.

\subsection{Limitations and Future Research}

This paper has two main limitations. First, because it is difficult to obtain data at the enterprise level, this paper selected provincial panel data, and some of the indicators are relatively basic. For instance, this paper uses the number of intellectual property rights infringement cases to evaluate regional legal systems. Although this measurement can reflect the level of development of a regional legal system to a certain extent, it is still inadequate. Therefore, future research should optimize the data and use micro-level data to analyze the impact of the institutional environment on enterprises' green innovation efficiency, which is of great significance in terms of improving the overall level of green innovation efficiency in China and other developing countries. Second, this paper generally explores but does not categorize the influence of the institutional environment on the relationship between 
reverse technology spillover effects and green innovation efficiency. Therefore, in the future, research should be optimized based on the characteristics of the regional development imbalances of different areas, and this should constitute a major direction of future research. Finally, future research should adopt an international perspective from which to study the influence of the institutional environment on green innovation efficiency in different developing countries because the institutional environment is of great significance for these countries in terms of improving their systems and improving their levels of green innovation efficiency.

\section{Conclusions}

\subsection{Reverse Technology Spillover Effects and Green Innovation Efficiency}

In this paper, we use data from G20 countries and China's OFDI data to measure the effects of reverse technology spillovers and adopt a threshold effect model for empirical analysis, based on China's provincial panel data from 2003 to 2015. The results show that reverse technology spillover effects can effectively improve green innovation efficiency. When Chinese enterprises establish subsidiaries in host countries for OFDI purposes, they will inevitably be constrained by local environmental regulations and the local legal systems; therefore, the subsidiaries are likely to enhance their sense of green innovation while absorbing technology spillovers from host countries. Moreover, parent companies can receive reverse technology spillovers and gain a more advanced awareness of green innovation through their interactions with subsidiaries in terms of technology, knowledge and personnel. When parent companies' technical level and awareness of green innovation have significantly improved and they are in a leading position in the production industry, the "learning effect" and the "catch-up effect" will drive other enterprises in the industry to accelerate their pace of independent innovation. The improvement of the industry's overall levels of technical proficiency and innovation awareness then promotes the adjustment and modernization of the home country's industrial structure, which advances the home country's green innovation efficiency level.

\subsection{Institutional Environment}

\subsubsection{Legal System}

This paper uses the number of intellectual property infringement cases to evaluate the regional legal system. The empirical results show that the impact of reverse technology spillover effects on the level of regional green innovation efficiency is more significant when the regional legal system reaches the corresponding threshold requirement, and the influence of the legal system is more significant than that of the economic and social systems. This finding is consistent with the conclusion of Criscuolo's research, in which the significant influence of patent citation on reverse technology transfer in Europe was proved [4]. At present, only a few areas in China (Jiangsu, Zhejiang and Guangdong) have legal systems that have reached the threshold level, indicating that the legal system has become a key institutional bottleneck with respect to improving green innovation efficiency. Therefore, for developing countries, including China, paying attention to legal system deficiencies in the context of regional development imbalances, improving the legal system based on regional characteristics, and emphasizing the level of intellectual property protection are of great significance for improving green innovation efficiency in transition economies.

\subsubsection{Economic System}

This paper uses three indicators, namely, the government's support for enterprises, the government's support for science and technology, and the government's support for education, in order to evaluate the regional economic system. The results show that China's economic system is relatively well developed; only a few economically backward areas (Hainan, Qinghai and Ningxia) have not met the threshold requirement. The effect of government support is 
obvious, especially in China. The government's support for enterprises can motivate enterprises to generate green innovation. The government's support for science and technology can promote overall improvement in technology, thereby accelerating outward foreign investment enterprises' absorption of external technology, promoting feedback and absorption efficiency and improving green innovation efficiency. In addition, the government's support for education can motivate foreign investment enterprises to value green innovation and green performance and to take social responsibility and increase their environmental awareness and, as a result, lead to the overall improvement of green innovation efficiency in China.

\subsubsection{Social System}

This paper uses social security expenditure and environmental protection expenditure to evaluate the regional social system. The results show that the impact of reverse technology spillover effects on green innovation efficiency increases significantly when social security expenditure and environmental protection expenditure meet certain threshold requirements. On the whole, the social system in various parts of China is relatively well developed, and only a few areas (Tianjin, Hainan, Ningxia and Xinjiang) have not reached the threshold requirement in terms of environmental protection expenditure and social security expenditure. When the social system in other areas meets the threshold requirement, its impact on the relationship between reverse technology spillover effects and green innovation efficiency increases significantly. Social security expenditure and environmental protection expenditure are important policy tools that push the industrial structure to improve in an environmentally friendly direction. Accurate understanding of the mechanisms through which environmental protection expenditure and social security expenditure affect the improvement of green innovation efficiency provides decision-making references on the basis of which the government can formulate and implement relevant environment-related fiscal and taxation policies and promote industrial structure adjustment. Especially in China, social security expenditure can promote social equity, motivate enterprises to participate in green innovation, and indirectly improve regional green innovation efficiency. As a market-based policy tool, environmental protection expenditure encourages regional producers and consumers to adjust modes of production through a clear value signal and as a result drives the improvement of regional green innovation efficiency. Therefore, developing countries, including China, should improve regulations relevant to budget transfers and payment for green innovation and help increase overall green innovation efficiency by improving the capacity for special transfers and payments.

Acknowledgments: This work was financially supported by the China Natural Science Foundation (71602016), the Social Science Planning Fund Project (L17CJL005), the Liaoning S\&T Project (201601054), the Science Foundation of the Ministry of Education of China (16YJC630025), the China Postdoctoral Science Foundation (2016M591439), the Provincial Nature Science Foundation of Guangdong (No. 2015A030310271 and 2015A030313679), and the Zhongshan City Science and Technology Bureau Project (No. 2017B1015).

Author Contributions: Yang Gao, Sang-Bing Tsai, and Xingqun Xue wrote the paper; Tingzhen Ren and Xiaomin Du contributed cases and ideas; Sang-Bing Tsai, Quan Chen and Jiangtao Wang provided advice on the revision.

Conflicts of Interest: The authors declare no conflicts of interest.

\section{References}

1. Kogut, B.; Chang, S.J. Technological capabilities and Japanese foreign direct investment in the United States. Rev. Econ. Stat. 1991, 73, 401-413. [CrossRef]

2. Nigel, D.; James, H.L. Foreign direct investment, technology sourcing and reverse spillovers. Manch. Sch. 2003, 71, 659-672.

3. Zhu, J.; Huang, W. Regional differences of OFDI reverse technology spillover effect: An empirical analysis based on China's provincial panel data. Int. J. Sci. 2017, 4, 86-92.

4. Criscuolo, P. Reverse technology transfer: A patent citation analysis of the European chemical and pharmaceutical sectors. Spru Working Paper. 2003, 27, 1406-1416. 
5. Branstetter, L. Is foreign investment a channel of knowledge spillovers? Evidence from Japan's FDI in the United States. NBER Work. Paper 2006, 10, 1-38. [CrossRef]

6. Nigel, D.; James, H.L.; Yong, Y. Technology sourcing and reverse productivity spillovers in the multinational enterprise: Global or regional phenomenon. Br. J. Manag. 2014, 25, S24-S41.

7. Wong, S.K.S. Environment requirements, knowledge sharing and green innovation: Empirical evidence from the electronics industry in China. Bus. Strategy Environ. 2013, 22, 321-338. [CrossRef]

8. Anastas, P.T.; Warner, J.C. Green Chemistry Theory and Practice; Oxford University Press: New York, NY, USA,1998.

9. Teece, D.J. Foreign investment and technological development in Silicon Valley. Calif. Manag. Rev. 1992, 34, 88-106. [CrossRef]

10. Lichtenberg, F.R.; Potterie, B.P. Does foreign direct investment transfer technology across borders? Rev. Econ. Stat. 2001, 83, 490-497.

11. Hsu, W.C.; Gao, X.; Zhang, J.; Hsinmei, L. The effects of outward FDI on home-country productivity-do location of investment and market orientation matter? J. Chin. Foreign Trade Stud. 2011, 4, 1754-4408.

12. Liu, X.; Trevor, B. Innovation performance and channels for international technology spillovers: Evidence from Chinese high-tech industries. Res. Policy 2007, 36, 355-366. [CrossRef]

13. Bai, J. The effect of the reverse technology spillover of Chinese outward direct investment on TFP: An empirical analysis. World Econ. Study 2009, 8, 69-89.

14. Cohen, W.M.; Levinthal, D.A. Absorptive capacity: A new perspective on learning and innovation. Adm. Sci. Q. 1990, 35, 128-152. [CrossRef]

15. Jian, L.; Roger, S.; Lutao, N.; Dylan, S. Outward foreign direct investment and domestic innovation performance: Evidence from China. Int. Bus. Rev. 2016, 25, 1010-1019.

16. Findlay, R. Relative backwardness, direct foreign investment and the transfer of technology: A simple dynamic model. Q. J. Econ. 1978, 92, 1-6. [CrossRef]

17. Kokko, A. Technology, market characteristics and spillovers. J. Dev. Econ. 1994, 43, 279-293. [CrossRef]

18. Herzer, D. The long-run effect of outward FDI on domestic output in developing countries. Appl. Econ. Lett. 2011, 18, 1355-1358. [CrossRef]

19. Hu, H.W.; Cui, L. Outward foreign direct investment of publicly listed firms from China. Int. Bus. Rev. 2014, 23, 750-760. [CrossRef]

20. Long, C.; Yang, J.; Zhang, J. Institutional impact of foreign direct investment in China. World Dev. 2015, 66, 31-48. [CrossRef]

21. Nigel, D.; Love, J.H.; Yong, Y. Reverse international knowledge transferring the MNE. Res. Policy 2016, 45, 491-506.

22. Li, H.; Zhang, Y.A.; Lyles, M. Knowledge spillovers, search, and creation in China's emerging market. Manag. Org. Rev. 2013, 9, 395-412. [CrossRef]

23. Bitzer, J.; Kerekes, M. Does foreign direct investment transfer technology across borders? New Evidence. Econ. Lett. 2008, 100, 355-358. [CrossRef]

24. Lee, J.; Mo, J. Analysis of technology innovation and environmental performance improvement in aviation sector. Int. J. Environ. Res. Public Health 2011, 8, 3777-3795. [CrossRef] [PubMed]

25. Fussler, C.; James, P. Driving Eco-Innovation: A Breakthrough Discipline for Innovation and Sustainability; Pitman Publishing: London, UK, 1996.

26. Blattel-Mink, B. Innovation towards sustainable economy the integration of economy and ecology in companies. Sustain. Dev. 1998, 6, 49-58. [CrossRef]

27. Mirata, M.; Emtairah, T. Industrial symbiosis networks and the contribution to environmental innovation: The case of the landskrona industrial symbiosis programme. J. Clean. Prod. 2005, 13, 993-1002. [CrossRef]

28. Porter, M.E.; Van der Linde, C. Toward a new conception of the environment competitiveness relationship. J. Econ. Perspect. 1995, 9, 97-118. [CrossRef]

29. Kemp, R.; Arundel, A. Survey indicators for environmental innovation. Idea 1998, 9, 37-42.

30. Zailani, S.; Iranmanesh, M.; Nikbin, D.; Jumadi, H.B. Determinants and environmental outcome of green technology innovation adoption in the transportation industry in Malaysia. Asian J. Technol. Innov. 2014, 22, 286-301. [CrossRef]

31. Handfield, R.; Walton, S.; Sroufe, R.; Melnyk, S.A. Applying environmental criteria to supplier assessment: A study in the application of the analytical hierarchy process. Eur. J. Oper. Res. 2002, 141, 70-87. [CrossRef] 
32. Kiefer, C.P.; Carrillo-Hermosilla, J.; Del Río, P.; Barroso, F.J.C. Diversity of eco-innovations: A quantitative approach. J. Clean. Prod. 2017, 166, 1494-1506. [CrossRef]

33. Horbach, J.; Ramer, C.; Rennings, K. Determinants of eco-innovations by type of environmental impact-the role of regulatory push/pull, technology push and market pull. Ecol. Econ. 2012, 78, 112-122. [CrossRef]

34. Arfi, W.B.; Hikkerova, L.; Sahut, J.M. External knowledge sources, green innovation and performance. Technol. Forecast. Soc. Chang. 2017. [CrossRef]

35. Negev, M.; Paz, S.; Clermont, A.; Pri-Or, N.G.; Shalom, U.; Yeger, T.; Green, M.S. Impacts of climate change on vector borne diseases in the mediterranean basin-implications for preparedness and adaptation policy. Int. J. Environ. Res. Public Health 2015, 12, 6745-6770. [CrossRef] [PubMed]

36. Bhore, S.J. Paris agreement on climate change: A booster to enable sustainable global development and beyond. Int. J. Environ. Res. Public Health 2016, 13, 1134. [CrossRef] [PubMed]

37. Frankel, J.A.; Rose, A.K. Is trade good or bad for the environment? Sorting out the causality. Rev. Econ. Stat. 2005, 87, 85-91. [CrossRef]

38. Cainelli, G.; Mazzanti, M.; Montresor, M. Environmental Innovations, local networks and internationalization. Ind. Innov. 2012, 19, 697-734. [CrossRef]

39. Pao, H.T.; Tsai, C.M. Multivariate granger causality between $\mathrm{CO}_{2}$ emissions, energy consumption, FDI and GDP: Evidence from a panel of BRIC countries. Energy 2011, 36, 685-693. [CrossRef]

40. Cheung, K.Y.; Lin, P. Spillover effects of FDI on innovation in China: Evidence from the provincial data. China Econ. Rev. 2004, 15, 25-44. [CrossRef]

41. Hart, S.L. A natural resource-based view of the firm. Acad. Manag. Rev. 1995, 20, 986-1014.

42. Berglund, M.; Borjesson, P. Assessment of energy performance in the life-cycle of biogas production. Biomass Bioenergy 2006, 30, 254-266. [CrossRef]

43. Demirel, P.; Kesidou, E. Stimulating different types of eco-innovation in The UK: Government policies and firm motivations. Ecol. Econ. 2011, 70, 1546-1557. [CrossRef]

44. Huang, G.; Ali, S. Local sustainability and gender ratio: Evaluating the impacts of mining and tourism on sustainable development in Yunnan, China. Int. J. Environ. Res. Public Health 2015, 12, 927-939. [CrossRef] [PubMed]

45. Worthington, I.; Patton, D. Strategic intent in the management of the green environment within SMEs: An analysis of the UK screen-printing sector. Long Range Plan. 2005, 38, 197-212. [CrossRef]

46. Etzion, D. Research on organizations and the natural environment, 1992-Prensent: A review. Rev. Art. 2007, 33, 637-664.

47. Darnall, N.; Henriques, I.; Sadorsky, P. Adopting proactive environmental strategy: The influence of stakeholders and firm size. J. Manag. Stud. 2010, 47, 1072-1094. [CrossRef]

48. Lin, R.J. Using fuzzy DEMATEL to evaluate the green supply chain management practices. J. Clean. Prod. 2013, 40, 32-39. [CrossRef]

49. Chen, J.; Cheng, J.; Dai, S. Regional eco-innovation in China: An analysis of eco-innovation levels and influencing factors. J. Clean. Prod. 2017, 153, 1-14. [CrossRef]

50. Guan, J.; Chen, K. Measuring the innovation production process: A Cross -region empirical study of China's high-tech innovation. Technovation 2010, 30, 348-358. [CrossRef]

51. Sun, L.; Miao, C.; Yang, L. Ecological-economic efficiency evaluation of green technology innovation in strategic emerging industries based on entropy weighted TOPSIS method. Ecol. Indic. 2017, 73, 554-558. [CrossRef]

52. Liang, X.; Si, D.; Zhang, X. Regional sustainable development analysis based on information entropy-Sichuan province as an example. Int. J. Environ. Res. Public Health 2017, 14, 1219. [CrossRef] [PubMed]

53. Merem, E.; Robinson, B.; Wesley, J.M.; Yerramilli, S.; Twumasi, Y.A. Using GIS in ecological management: Green assessment of the petroleum activities in the state of Texas. Int. J. Environ. Res. Public Health 2010, 7, 2101-2130. [CrossRef] [PubMed]

54. Sandmo, A. Efficient environmental policy with imperfect compliance. Environ. Resour. Econ. 2002, 23, 85-103. [CrossRef]

55. Requate, T. Timing and commitment of environmental policy, adoption of new technologies and repercussions on R\&D. Environ. Resour. Econ. 2005, 31, 175-199.

56. Miranda, M.L.; Edwards, S.E.; Keating, M.H. Making the environmental justice grade: The relative burden of air pollution exposure in the United States. Int. J. Environ. Res. Public Health 2011, 8, 1755-1771. [CrossRef] 
57. Hall, B.H.; Helmers, C. The role of patent protection in (clean/green) technology transfer. NBER Work. Paper 2010, 26, 487-532.

58. Cooper, N.; Green, D.; Meissner, K.J. The Australian national pollutant inventory fails to fulfill its legislated goals. Int. J. Environ. Res. Public Health 2017, 14, 478. [CrossRef] [PubMed]

59. Ali, M.; Cantner, U.; Roy, I. Knowledge spillovers through FDI and trade: The moderating role of quality-adjusted human capital. J. Evolut. Econ. 2016, 26, 837-868. [CrossRef]

60. Chen, V.Z.; Li, J.; Shapiro, D.M. International reverse spillover effects on parent firms: Evidences from emerging-market MNEs in developed markets. Eur. Manag. J. 2012, 30, 204-218. [CrossRef]

61. Xiao, S.S.; Jeong, J.; Moon, J.J.; Chung, C.C.; Chung, J. Internationalization and performance of firms in China: Moderating effects of governance structure and the degree of centralized control. J. Int. Manag. 2013, 19, 118-137. [CrossRef]

62. Jennings, V.; Larson, L.; Yun, J. Advancing sustainability through urban green space: Cultural ecosystem services, equity, and social determinants of health. Int. J. Environ. Res. Public Health 2016, 13, 196. [CrossRef] [PubMed]

63. Hansen, B.E. Threshold effects in non-dynamic panels: Estimation, testing, and inference. J. Econom. 1999, 93, 345-368. [CrossRef]

64. Scott, W.R. Institutions and organizations. Cine J. 1995, 24, 469-470.

65. Oxley, J.E. Institutional environment and the mechanisms of governance: The impact of intellectual property protection on the structure of inter-firm alliances. J. Econ. Behav. Org. 1999, 38, 283-309. [CrossRef]

66. Spencer, J.W.; Gomez, C. The relationship among national institutional structures, economic factors, and domestic entrepreneurial activity: A multicountry study. J. Bus. Res. 2004, 57, 1098-1107. [CrossRef]

67. Li, M.; Yuan, X.; Zhang, Y. Institutions and reverse technology spillovers from OFDI. World Econ. Study 2014, 2, 61-66.

(C) 2018 by the authors. Licensee MDPI, Basel, Switzerland. This article is an open access article distributed under the terms and conditions of the Creative Commons Attribution (CC BY) license (http://creativecommons.org/licenses/by/4.0/). 